\title{
Rationalizing poverty in New York: Tales from the middle class
}

\author{
Samira Ali, Carolina Ohls, Gary Parker, Robert Walker
}

\begin{abstract}
Although poverty rates in the US are among the highest in the OECD, there is limited public support for a new war on poverty and persistent opposition the provision of generous welfare. This article addresses the long-standing puzzle of why such attitudes have proved so resistant to change. Based on focus groups discussions, this article offers the suggestion that this resistance may be due to public attachment to a shared conceptual model of poverty. The model embraces the American dream and a belief that opportunity enables anybody with adequate effort to achieve all their aspirations.

Poverty; Social Welfare Policy; Social Policy; Families in Poverty; Focus Group
\end{abstract}




\section{Introduction}

More than 50 years after President Lyndon B. Johnson launched the War on Poverty, poverty in the United States remains among the very highest in the OECD (Organization for Economic Co-operation and Development), exceeded only by Israel and Mexico (OECD, 2016). Johnson's reforms had some initial positive effects and the legislation that established Medicaid, Medicare and Food Stamps (later renamed Supplemental Nutrition Assistance Program (SNAP)) still constitutes the core policy infrastructure. But the initial momentum was not sustained. Instead, there has been a long period of sustained retrenchment punctuated by the occasional large scale progressive reforms such as the introduction of the Earned Income Tax Credit (EITC) and the heavily contested Affordable Care Act (ACA). More typical was the metamorphosis of Aid to Families with Dependent Children ADFC into Temporary Aid to Needy Families (TANF) in 1996 when the USA became the first country ever to abolish a universal scheme of last resort.

The reasons for the lack of political will to tackle poverty are much debated (Holman al., 2017; Alesina and Glaeser, 2004). They include institutional factors that block redistribution such as majoritarian voting systems, federalism embracing states of very diverse character and interest group politics fueled by wealth combined with weak trade unionism. Taking a longer-term view, Alesina and Glaeser (2004) suggest that economic and military success have curtailed pressures for radical reform as has the salience of race and racism that equates welfare with people of color. In recent times, there has also been little public appetite for progressive reform with only about half of Americans believing that 'dealing with problems of the poor and needy should be a top priority'; in opinion polls the topic rarely appears above tenth in the list of issues requiring the attention of federal government (Haskins, 2016). Indeed, the World Values Survey reveals that in the 2000s that 
the proportion of people attributing poverty to laziness in the USA (62 per cent) was exceeded only by the Philippines, Taiwan and Puerto Rico (Walker, 2014).

The Great Recession seemed to shift public opinion as to the main causes of poverty. In 1995, around the time of the TANF reforms, Americans were twice as likely to believe that poverty 'resulted from people not doing enough to help themselves out' than to attribute it to external forces, whereas, by 2014, respondents were evenly split in prioritizing structural as opposed to individualistic reasons (O'Connor,2014). Indeed, partly for this reason, some commentators argued that poverty and lack of social mobility should, or would, feature strongly in the 2016 presidential campaign (Halpin and Agne [2014] and Stephenson [2016] respectively). Also, Republicans seemed to have been goaded into action by polls that in 2012 showed that 80 per cent of voters believed that Obama cared more about people like themselves than did Romney. In January 2016, many of the aspirant Republican candidates assembled in Columbia, South Carolina, for a forum on poverty and opportunity sponsored by Jack Kemp Foundation (Haskins, 2016). Donald Trump was notably absent and, with his success in the primaries - possibly appealing to voters at risk of poverty, public attention shifted from policies to personalities. A topic of more salience among Democrat voters, Bernie Sanders the most long-standing of the unsuccessful candidates for the Democratic nomination, included poverty in the long list of social issues that fueled his campaign using rhetoric that, for example, equated US poverty with a death sentence and that drew parallels between neighborhoods in Baltimore and ones on the Palestinian West Bank (Haaretz, 2016). Even so, despite the unexpected success of Sanders' campaign, poverty was not a particularly salient issue in Hilary Clinton's ultimately unsuccessful campaign.

Moreover, other opinion poll data suggest that the American public may have reverted to type. Even by 2012 the proportion of Americans believing that 'It's the government's responsibility to take care of people who can't take care of themselves' had fallen back to 59 
per cent from an exceptional high of 69 per cent in 2007 (PRC, 2012). The proportion thinking that 'the government should help more needy people even if it means going deeper in debt' correspondingly fell from 54 per cent to 43 per cent during the same time period. In 2015, the proportion believing 'dealing with problems of the poor and needy should be a top priority' was 55 percent, two percentage points down on 1997; it had been as low as 49 percent in 2014 (PRC, 2015). Research that has directly explored the determinants of individuals' attitudes has confirmed the role of rising unemployment and the Great Recession in increasing support for anti-poverty policies (Campbell, 2016). Also important are demographics (support falls with age (PRC, 2012)), political beliefs (Republicans are more less supportive than Democrats (PRC, 2012)), personal self-interest (support declines with increasing affluence (Hasenfeld, and Rafferty, 1989)) and financial vulnerability (those in insecure employment favor targeted government spending (Owens and Pedulla, 2014; Margalit, 2013)).

While there is debate about whether the shift in attitudes associated with the Great Recession or, indeed coincident with the War of Poverty, could ever have been sustained, there is considerable agreement that political anti-poverty rhetoric is likely to drown out propoor sentiment. Santiago $(2015$, p. 6) talks of a 'war on the poor', in which the 'ideology of undeservingness became a primary weapon' and that policies known to work, such as job creation and workforce development and social entrepreneurship, were rejected. She agrees with Rose and Baumgartner (2013, p. 22) that:

Media discussion of poverty has shifted from arguments that focus on the structural causes of poverty or the social costs of having large numbers of poor to portrayals of the poor as cheaters and chiselers and of welfare programs doing more harm than good.

Santiago (2015) further links this rhetoric to opinion polls which reveal that the majority of people attribute poverty to welfare policies that are believed to inhibit initiative and to 
personal deficits that weaken family supports. Similarly, Wise (2014) documents a discourse, which he labels 'poverty denial', based on three widespread beliefs: that people poor in America are 'fabulously wealthy' in global terms; that people in poverty waste their money on luxuries and that large numbers of welfare recipients are defrauding the system. Research that specifically investigates the role of political discourse on individual attitudes is limited in the US (Brown, 2013) but Campbell (2016) shows that personal history and prior experience of poverty are important mediators together with a pervasive distaste for welfare benefits .

Campbell's analysis finds substantial support in literature grounded in social and political psychology (Feagen, 1975; Kluegel and Smith,1981; Hunt, 2016). Attribution theory suggests that people seek to account for aspects of the social world in causal terms and variously attribute poverty to individualistic, structural and, less so in the USA than elsewhere, to ill-luck. People often simultaneously endorse individualistic and structuralist beliefs (variously termed 'dual' [Hunt,1996] or 'split' 'consciousness' [Kluegel et al., 1995]), the former in the US constituting the 'dominant ideology' of 'economic individualism', the latter being informed 'more from the practical realities of people's lives' (Hunt and Bullock, 2016, p.103). Furthermore, they are encouraged to do so by 'legitimating myths' (Sidanius and Pratto, 1999) that serve to justify the existing social order (Jost et al., 2012) and which are often most powerful when the system appears under threat or when individuals feel that they have low personal control (Godfrey and Wolf, 2016).

Such attributions and negative public attitudes towards welfare and tacking poverty must go some way towards explaining the lamentable record of the USA in curbing poverty compared to other countries. But much less well understood is why these attitudes have proved so resistant to change. This article poses the possibility that this resistance may be due to the public's attachment to an explanatory model of poverty that embraces the 
American dream and a belief that opportunity enables anybody to achieve anything provided that they exert adequate effort. This reasoning derives from group discussions held with middle class New Yorkers in 2014 to explore their conceptions of poverty. New York is perhaps a special case, a city with great extremes of wealth, but the model, explicated below, is so resonant of American values that it warrants further empirical investigation in other parts of the US.

\section{Method}

Middle class ${ }^{\mathrm{i}}$ respondents were recruited to participate in focus groups ${ }^{\mathrm{ii}}$ as one component of a larger project examining the relational and socio-psychological dimensions of poverty in New York. While the core study was located in three of the poorest ZIP codes in New York, each contained more affluent neighborhoods and was surrounded by rapidly gentrifying areas. The respondents were recruited from these neighborhoods through purposive sampling from various community centers and boards throughout the gentrifying neighborhood surrounding the three zip codes, via email and by means of word of mouth. Fifty-two eligible individuals were approached and 27 took part in total of six focus groups. While by definition participants were not necessarily representative of middle class New Yorkers, their proximity to people living in poverty was thought to be salient in exploring the relational aspects of poverty. In the event, very few respondents had any direct contact with people in poverty. Participants received $\$ 30$ and a round trip subway card for their participation. The study was approved by the New York University Institutional Review Board.

The groups varied in size and composition giving a distinctive flavor to each of the discussions (Table 1). Overall, the mean age of participants was 44, 18 were female, almost all had children and a majority were married. Most participants were born in the US; just under half of the participants self-identified as African American, a little more than a fifth as Latino, and the remainder variously as white, Asian, South American or African. 
Occupations included court attorneys, civil servants, business administrators, certified public accountants, researchers, and business owners.

(Insert Table 1 Here)

The group sessions were audio recorded and the recordings transcribed for analysis using a variant of semantic mapping, a qualitative technique that allows the logical reasoning of individuals and the cut and thrust of conversation to be retained while simultaneously undertaking a thematic analysis (Jones, 1985). Adopting a grounded theory approach, (Glaser and Strauss, 1967, the analysis was inductive and revealed a coalescence of respondents' views around the conceptual model, or cultural schema (Strauss and Quinn, 1997; Holman et al, 2017), summarized as Figure 1, the arrows indicating respondents' beliefs about pathways of causation or influence. Poverty was generally defined by respondents in attitudinal terms as much as with respect to material deprivation. People in poverty were deemed to lack motivation, make the wrong choices and associate with the wrong people all of which served to perpetuate poverty and to reproduce it across the generations. Nevertheless, poverty was seen as structural in its causation. Economic factors, social processes and policy interventions conspired to limit opportunity and/or to channel people along deleterious life courses. Moreover, these structural constraints were commonly considered to have increased in recent decades.

The remainder of the article explicates this model with reference to extracts from the group discussions with an invitation to readers to subject the model to critical review and to test its validity and reliability in other localities and through different research methods.

\section{Results}

(Insert Figure 1 here)

\section{Knowing about poverty}


There was little doubt among participants in the focus groups that poverty existed in New York. Whereas the middle class in Europe might spontaneously quibble that real poverty now only existed in places such as sub-Saharan Africa and that what passed as poverty locally was only financial hardship, poverty in New York was taken for granted (Chase and Bantebya-Kyomuhendo, 2015). This is not to say that people had given much thought to what poverty was for most only had a passing acquaintance with it. They saw people soliciting on the subways and in the streets. They could spot young people 'without ambition and education' as they travelled uptown on the 6-Line Subway. They had heard of families living in 'the projects' (public housing) for a number of generations.

I: What do you think the typical New Yorker's interaction is with someone who is poor or facing financial hardship?

R1: I think a lot of the interaction could be on the subways, on the streets. There's a lot of homeless people that are on the streets. I think there's a lot of segregation. Areas are gentrifying. They are seeing less and less of the other side. Maybe you walk by them on the street and that's about it.

R2: Yeah, and I've seen that on the subway where organizations come with food and they'll just give food to anybody who like wants it..., like if you're just hungry, like here is a peanut-butter and jelly sandwich or a banana or a Capri Sun or whatever it is. $5 / 24-25$

Some professionals, social workers and public officials, encountered people in poverty as clients often when they came to them in trouble. Occasionally respondents talked of persons within their own families, typically distant kin and usually of an older generation. Only very rarely were people in poverty included among those mentioned as friends. An exception was a friendship mentioned by one respondent that had begun in school; even here, however, the financial difficulties had not been appreciated at the time but were revealed much later in an exchange on Facebook. In another similar instance, the husband of a respondent's friend had first been without work, then needed two jobs to get by but still failed to prevent foreclosure on their house. However, the respondent only realized the implications of all of this when she employed the friend's daughter as a nanny and detected that something was wrong from 
the girl's behavior and from that pieced together that the issue was one of poverty. She further deduced that her friend's financial circumstances must have improved because she was still living in the same house but she did not know for sure since these were not things that one spoke about.

And I saw a good friend of mine that I grew up with go through this. Her husband lost his job they have five children and they went on public assistance. She didn't talk about it...I don't even know if she's still on it or not, but---because I know that her husband is working two different jobs right now. (2)2/15/3

A not inconsiderable number of respondents had experienced poverty either directly or indirectly early in life. One remembered from childhood how no one wanted to play with children from low income neighborhoods and how such children were bullied in $5^{\text {th }}, 6^{\text {th }}$ and $7^{\text {th }}$ grade. Others recounted their parents claiming social assistance, in one case clearly fraudulently. Others had themselves claimed welfare when young and bringing up children. One respondent recounted how after her divorce and with young children to care for she was not coping; her boss had suggested redundancy so that she could claim welfare and Food Stamps which she then did for five years. Another asked her boss to cut her hours so that she could claim welfare and boost her income although she was then accused of dishonesty. Another claimed welfare while trying to finish college. They generally recognized that poverty had meant hard choices and some still remembered the emotional relief of coming off welfare.

My parents come from another country, you know, they make do, my dad worked. And my mom worked and when I was born, they - she - got on public assistance. She's been on public assistance for 43 years.... She worked for years. My dad told her, Don't work, you need to be a stay at home mom.' My dad paid all the bills, took care of the family, did everything. But when she went to a face-to-face hearing to renew her assistance, my dad wasn't my dad. I didn't know my dad. That's how she worked the system. (3)6/31/3

I came across my old, my old card with the picture, that picture ID and I still have it. I think back and you know, I did what I had to do. And I don't feel any shame on it, you know, I did then. I don't anymore. It was my, it was my stepping stone and I, as soon as I was able to like get off of it, I closed the case. (3)6/75/1 


\section{Mental poverty}

While a dictionary might define poverty as having little money or few possessions, people in discussion seemed often to see material poverty as either the product, or a cause, of a more profound poverty, variously termed 'mental poverty' or 'a poverty of spirit'. The complexity, not to say the conflicted nature, of this thinking is illustrated by the following exchange:

R5: Poverty is economic poverty and that breeds poverty of spirit.

R2: And there's mental poverty.

R5: Poverty of spirit and you can't even get out of bed in the morning because things are so miserable.

R3: Except that if the money is not on your card, you'll find a way out of your bed.

R2: Emotional poverty and.....

I: Can we talk a little bit more about what you're calling emotional poverty?

R5: I just see it a lot in my work; when the people come into this office and the people I talk to on the phone, yeah, it's a lack of hope. I see that and it's very disturbing. It's very upsetting. And I have to spend an enormous amount of time basically propping people up, trying to tell them 'yeah, there is a tomorrow'.

I: Where do you think that comes from? Where do....?

R4: Lack of religious beliefs.

R2: And it's a generational thing...

R5: I just think that they find themselves in a place and unlike all of us who face challenges, they don't have the wherewithal to rise to the occasion and fight back. They need somebody to do that for them...

R4: That's where you go maybe to your priest, maybe you should go and pray because I prayed on a lot of stuff ... But you have to say that 'I'm willing to make the effort to try and if I had to scrub toilets then that's what I will do'. (4)1/38-9/

For respondent R5, the poverty of spirit follows from economic poverty but then is entwined in people's inability to confront the challenges born of material deprivation. For the others, the lack of spirit precedes, or at least helps to explain, economic poverty; it is a personal 
deficiency that may reflect modern generational values (respondent R2), come from within (respondent R4) or be a product of the existence of welfare softening the discipline of the labor market (respondent R3). Thus, in the eyes of the New Yorker of moderate means, poverty has behavioral and moral dimensions that are inextricably connected with its material manifestations. These no doubt shape the public attitudes to people living in poverty and help to explain to the conditional support for welfare provision.

Mental poverty, poverty of spirit, is widely construed as having multiple dimensions of which perhaps the most important are lack of motivation, making 'wrong' choices and associating with the wrong people (Figure 1). Lack of motivation is, like mental poverty itself, variously thought to be a product of poverty, the result of people being discouraged by repeated set-backs in life and the enormous challenges of just surviving, let alone making a real life out of living on a low income:

I think if you are not born into it, you fall into it and it might be just poor decisions that you have made. Like if you had opportunities in life and you didn't take them and you just end up in poverty by accident. Or you might have made a poor business decision and then lost your business, lost your home, lost your family or whatever and you end up in poverty. You just made poor decisions in life, you decided to go with the wrong route; join a gang or whatever, worst case scenario. (2)5/7/1

But for some, lack of motivation is no more than a euphemism for laziness, a personal trait sometimes interpreted in spiritual, evangelical terms as being the human condition prior to redemption. Certainly, a rich discussion involving some first generation migrants from subSaharan Africa included references to moral and cultural dimensions. The US was thought to differ from Africa in that welfare provisions in the former meant that the lazy man would not starve; this was in marked contrast to an African saying 'No food for the lazy man' that aptly captures the view of many respondents. People talked of complacency and a lack of initiative, the need to have personal goals beyond the situation in which people find themselves. For many respondents, poverty was seen to be the inevitable consequence of this 
failure, the flip side of the work ethic and the American dream that 'the heights of great men are reached by toiling'. People were condemned by complacency to social immobility from which they would not escape unless they realized discontentment. Those of an overtly religious disposition were inclined to believe that escape might only be possible through the power of prayer. One spoke of people's 'enslavement to circumstance', while a pastor believed that people lived 'stagnant lives' and that change was impossible without inspiration and that 'All inspiration... belongs to God'.

One of the major reasons is laziness... my father always said that "Hard work killed nobody, it makes you stronger." With that kind of mentality, you got to work, you have to be ready to do anything to advance yourself. Secondly, people are poor because they lack initiative; in other words, you have to be in a position where you are not comfortable with what you are living. ... You have to have that kind of attitude: 'I don't want to live like this anymore'. OK? And my third reason is mindset. The mind-set of people they want to plant seeds today, they want to begin harvesting tomorrow. It can't work that way. (1)3/5/4-6

The failure to make the right choices, it was often contended, arose from this complacency, 'an unhealthy contentment'. The concerns of the present were placed ahead of the needs of the future. There was some recognition that this was because living in poverty meant that one was always having to 'weigh choices' with little margin for error. Equally, though, it was widely believed that many people were trapped in a 'block mentality', where their aspirations were set by the narrow focus of those who lived around them. School children chose not to work hard and to focus on college graduation since none of their peers did so, or because they saw no point in doing so. One respondent cited as evidence a 'little girl' with whom they had conversed who asserted 'I don't want to work because they do give me food every week.'

Some people argued that poverty was like a disease that festered, undermining both psychological and physical health. Low self-esteem, envy and anxiety could all lead to frustration and anger which might be internalized or erupt as violence and self-destructive 
behavior, drugs and alcohol abuse. This, it was argued, served to keep people in poverty rather than providing the much-needed stimulus for people to 'get out of poverty'.

[Poverty] is a disease. It affects every part of your life psychologically, physically, mentally and otherwise. Because when you don't have money to get what you need, even to put food on the table three times or even two times in a day, it is a problem. It leads kids into stealing, doing all kind of things, murder, you name it, prostitution and all that, just to make ends meet. (7)3/17/2

The maxim that 'if we move with a wise individual, you become wiser' cited in one group encapsulates another frequently expressed view that poverty is a product of choosing the wrong associates. Anyone associating with others who had no direction would themselves become directionless in life. Worse, they risked being tempted actively to choose to be poor, if only because they saw no need, or had no desire, to be different from their peers. Equally they might be tempted to adopt a life-style in which criminality replaced hard work or drugs and alcohol drowned out the pain of failure.

Almost all respondents conflated material and financial poverty with a poverty of spirit which two groups coined 'mental poverty', although the tenor of their discourse suggested something more akin to 'moral poverty', the failure to do the right thing. A small number of respondents held out against this conflation including a student who faced the concerted opposition of five older members of the African-American community but who continued to stress the structural causes of poverty linked to the economy and to aggressive advertising by large companies. Two women, both migrants from Europe, constructed their analysis of poverty through the lens of America's inadequate welfare state and refused to engage in the moralistic discourse. But these three were the exceptions.

\section{Antecedents of mental poverty}

While most respondents took the existence of poverty to be the product of people making the wrong choices, they did not all, or always, hold people in poverty personally to blame for their own circumstances. Rather they recognized a series of structural and circumstantial 
factors that served to frame or constrain choices. For reasons of exposition, these multiple influences can be categorized into three: social; ones relating to public policy; and economic

(Figure 1). Within each category respondents recognized processes which independently and together either limited people's opportunity sets or blinded them to them; they also referred to secular trends that they felt mainly served to increase the risk of poverty. In addition, these processes were perceived to be cumulative creating a cycle of poverty that crossed generations.

\section{Social processes}

The social forces most often identified were race, community and family (Figure 1). While perhaps not the most powerful of these social forces, people typically focused first on the role played by parents and the family in general. Very often respondents contrasted the positives that they perceived in their own parents with negatives that they presumed applied to others. Parents could be positive role models: working hard; taking multiple jobs when necessary; not giving up even when fate conspired against them; stressing the importance of education; supporting learning by tuition at home and engagement with school work; guiding children to make the right choices in life. Sometimes respondents were motivated by a desire to avoid the pressures and anguish that they had seen in their parents. Either way, many respondents credited their parents as the stimuli for their own success, life journeys that had seen some born into poverty but who had managed to leave housing projects and welfare behind. Other parents who failed to inculcate a belief in the value of education were thought to condemn their children to a life of poverty. Sometimes it was appreciated that this was because parents who had themselves missed out on schooling did not realize its value or because they were so busy working or 'hustling' that they had no time or energy adequately to support their offspring. As often, parents were condemned for not taking responsibility for their children or for indulging in poor parenting practices, not setting the correct standards and not teaching 
children to make the right choices. Rather than save up for college fees, they would placate their children with wasteful expenditure on keeping up appearances, putting short term demands ahead of longer term responsibilities. Some parents were characterized as lazy, disinterested and watching television all day; others as drug users and alcoholics.

Growing up on public assistance and watching my mom struggle for very little things. I said I don't want that life for myself. So I, you know, went to school and educated myself and I told my daughter: 'You're not going to be ever where I had to be'. I remind her all the time. We appreciate everything we have because I know what it was like to go hungry. (1)6/7/4

Sometimes there is no parental influence. There is none at all. If you have a woman who, 24 years old, crack addict woman, gives birth to a child, she raises him in the street or wherever, sends him off to kindergarten then, by the time he's eight or nine, she shoves him off to the grandmother ... She's just raising this kid because it was thrown at her. (1) $1 / 18 / 2$

Quite a few respondents felt that parents were not helped because standards of parenting had declined over time. Children, it was thought by some, were no longer afraid of their parents and were therefore more likely to get into trouble. Parents tried to be friends with their children rather than being parents and they were often fearful of the consequences of disciplining their children. Standards of social life had also fallen. Families were less strong, teenage pregnancies were common and a gang culture predominated in the projects.

Community was less strong than it once was. People did not any longer care either about their neighbors or their neighborhood and therefore failed to challenge disruptive elements. The networks of support and local intelligence that had supported their own parents were thought no longer to be present and parents were very much on their own. The neighborhood itself no longer provided positive role models. If the positive support of the neighborhood had weakened, the negative influence of racism was thought by African American respondents to condemn people of their race to remain poor. Discrimination remained in education, housing, employment and even when starting up a business. In private sector employment, black people were considered still to be the last to be hired and the first to be 
fired, while increased regulation had curtailed the 'hustling' that once enabled African Americans to advance economically. Racism, it was argued, meant generations of young men being sent unfairly to jail which split families, denied children access to their parents and created anger and resentment within communities. With a criminal record, young men were effectively excluded from employment and they and their families were denied public housing. One group concluded that certain cultures were 'targeted' and 'condemned to fail'.

I don't want you to think that we are not saying that racism doesn't happen. It has a huge impact on our community and it leads people to stay in poverty. That's the overriding, overarching condition ..., lack of opportunity in jobs, lack of opportunity in education, lack of opportunity in housing, just even starting businesses. (2)4/7/4

When they come out of jail, and there are a lot of young men in jail, they are limited in terms of what they can do. So it's a cycle, they go round and round. (1)4/12/3

The argument here is not only that racism removes opportunity but rather that in doing so it denies people and communities hope and young people the expectation of change since they are surrounded by others who are going nowhere.

Everybody knows everybody, nobody is looking forward to go anywhere... You have to separate yourself; it all has to do with the mind-set. It's all in the mind. If not, you are screwed; you are nailed down. 3/7/1

The despair about the impossibility of personal advancement was echoed in the group of African Americans by frustration with the failure of politics to respond to the needs of their community creating almost a siege mentality.

R1: There are laws in place; you protest now, you go to jail and you don't know when you are going to get out. You say the wrong word, they can snatch you off the street.

R2: That's right.

R1: Your rights are gone and it is so different now. I mean that is the stuff we did in the '60s. We made stuff happen too. But now they are arresting everybody.

R3: And you got to ask yourself too, how are these kids getting all those guns?

R1: Right, this is not rocket science.

R2: Exactly. 
R1: Drugs; they bring those drugs into the community and they bring those guns in our community...Y You can go twenty blocks down to the Italian community, you'll see no dirt, no guns and no drugs. Now why is that? Come here at night and you see the projects occupied by the police. Big spotlights, you can't even sleep.....

R3: If they wanted to stop those guns, they could. They don't want to... (8)4/38/

\section{Public policies}

Markedly contrasting views were evident about the role public policy in shaping what respondents construed to be 'poverty mind-sets'. On the one hand, inadequate policies regarding education, housing and health combined with a weak labor market to deny people opportunities and the means of escaping. Welfare provision, on the other hand, was seen by many to enable people to sustain a desired life style without the need for work, thereby contributing directly to the creation of a destructive mind-set (Figure 1).

Given that education was almost universally viewed as a bridge to a better life, it is perhaps not surprising that provision in New York, seen to vary markedly in quality between neighborhoods, came in for much criticism. Children in public education were said to lose out as the schools lacked resources to offer the right opportunities. Youngsters wanted to leave at the first opportunity and were consequently condemned to unemployment or, at best, poor badly paid jobs that, in turn, opened the door to the easy temptation of drugs and crime. Those from the African American community, in particular, also argued that the programs that had once been in place to fund college attendance had largely been closed and that even job training was hard to come by. This, combined with the aforementioned demise of neighborhood support networks that once highlighted people to such opportunities as there were, caused people to conclude that the only solution was to move to education outside of the 'ghetto'. This strategy, pursued personally by a number of respondents, was available only to those with sufficient resources.

The lack of affordable housing was identified as another policy that helped to perpetuate poverty. People simply could not afford to live in decent accommodation and 
experienced squalor that some respondents thought was no letter than living on the streets. Even people with jobs, it was said were forced to live in shelters for sustained periods while the disastrous educational experiences of homeless children led some respondents to suggest providing them with boarding schools 'as in Russia'. There was a tendency to refer to public housing projects as 'ghettos' and some respondents strongly believed that poor housing contributed to mental poverty, sapping the will to make progress. At the same time, people reported overhearing criticism of public housing for being too cheap, too heavily subsidized and thus making life too easy

There's not enough affordable housing. And the ones that are affordable for people in poverty are in horrible conditions.... And so when you're not taking care of them as human beings, then they're thinking 'I'm not worth anything'. It's perpetuating that cycle. If you already don't think you're worth it and then you're being provided facilities that make you feel like you're not worth it, how are you going to feel that's worth it to try to work harder, or whatever it is that one needs to do, to get out of poverty? (3)2/3/1

The cost of health care was scarcely ever mentioned other than to note that with Obamacare America was beginning to tackle this problem. Nevertheless, respondents saw ill-heath as being a cause of poverty preventing people from working that in turn caused mental health problems. Public health and health education programs were thought to be inadequate.

There was discussion about diet, obesity and associated disorders and the possibility that people in poverty were 'over-eating and under-nourishing'. Reasons considered to explain this included: lack of time and lack of space causing people to eat out; 'self-treating' - eating to compensate for life's pressures; ignorance of good nutrition combined with inadequate teaching in public schools; a failure of parents to response to diet conscious outreach and finally, the power of the food industry which continued to market strong, sweet tastes that were addictive especially to children. In response to this analysis and the perception that the problem was one of inadequate rather than insufficient food, some respondents advocated public education schemes as an alternative to providing food banks. 
If the above policies were considered inadequate in their coverage and quality and thereby failed to create sufficient opportunities for people to advance, the provision of welfare was widely understood to remove the incentive to seek out opportunities. Four sets of arguments were marshalled against welfare provision which caused some to call for its abolition:

The welfare program, get rid of it! It's supposed to have been a band aid situation during the depression, it shouldn't exist still today. (3)1/30/4

First, some considered that the very existence of welfare contributed to mental poverty creating a sense of unconditional entitlement to assistance that removed the incentive for work and personal improvement. People became dependent on the system finding it difficult to break a habit.

I think there're certain people that are, you know, in that situation and smart enough to say, why the hell should I try? This is better; this is easier. And that's where that attitude comes from. I think that, you know, because you do see people like that. (3) $2 / 4 / 3-3$

Secondly, welfare benefits were both too generous and long lasting. Whereas there might be a case for temporary minimum assistance to tide people over a crisis, it was believed that the existing system made it possible for people to choose a comfortable lifestyle funded from the public purse.

I'm in line behind a lady who literally looks like she was shopping for a group home. She had---and she was shopping from the front, she had a whole ton of stuff, had two little kids with her, they asked her for ID. You know what she took out for her ID? Her benefit card and I'm like: 'Really?' ... And it's just---I'm paying for their food. I don't understand how you're able to buy Cocoa Puffs and cakes---it's not essentials! (3) $1 / 31 / 3$

Thirdly, some considered that abuse of the system was widespread. People claimed welfare to which they were not entitled, supplemented their wages with public money and hid the men in their lives whenever benefit was to be assessed. Young women could be promiscuous since they knew, as single mothers, that the government would support them 
But it's at the point of abuse. On my way here, there's a known woman who a crack addict; there's no other way to put it, who was pregnant again. She has now five children plus the one coming. She's a mess....It's like, why would we continue to reward that? Then, I'm a real estate broker, a cop came to me, he has three children and a wife. They're not legally married. She's collecting welfare. (3)1/33/2

And finally, many respondents were convinced that welfare receipt was self-perpetuating.

Because life on welfare was comfortable, it removed any incentive to leave and better

oneself. This was an understanding that it was thought young people easily absorbed making it likely that they would follow their parents in choosing a life on welfare.

And if they're getting food stamps and there rent paid and you don't have to get up in the morning to go to work from 9 to 5. You get comfortable. Not that it covers everything, but they don't feel like well, they have to get up and go find a job...It's a cycle. It's they see their mother... I'm not going to say father because half of them aren't there. And their mother's on welfare, sitting down, doing nothing...If you see your parents, your mother doing this, they have no motivation. (3)6/25-7/3

These perceptions were generally not based on direct knowledge and were occasionally challenged by those who encountered people on welfare in their role as public officials. One, for example, argued that the computer systems now in place made cheating the system much more difficult than before and another documented the difficulties that people sometimes encountered getting access to assistance. Even so, some respondents were prepared to counter such assertions based on hearsay, casual observation and occasionally, apparently, hard evidence:

R5: I think there's a myth out there, everybody wants to talk about the woman who has food stamps, who pulls up in a Cadillac and buys sturgeon while you're buying tuna fish and you know, I don't really see that a lot.

R3: I was a case worker for four years; I saw it all the time. (1)1/37/7

\section{Economic factors}

The final set of factors that were thought to constrain opportunity and shape the behavior of people experiencing poverty linked to the working of the economy (Figure 1). In the group discussions these considerations were frequently alluded to but seldom discussed in detail. One key concern was marketing by large companies; this was thought to create unsustainable 
aspirations for consumption fueled by access to credit. A second concern was change in the labor market that reduced both wages and the chance of finding work.

It was generally believed that modern society was powered by consumption. People, it was thought, aspired to consume more and more and life-styles were framed around consumption. Children competed for recognition, friendships and leadership through accumulating and boasting about possessions. Adults were thought probably to do likewise and were actively encouraged to do so by big business, either directly through advertising or indirectly through media discussion and expectation building. While this was true irrespective of income, some people were considered to be poor as a consequence of overspending. Others were thought to overspend because they were poor; perhaps because they had less than they needed but more often because they wanted more than they could afford. Parents frequently caved in to children's demands to buy things rather than teaching them the value of money. Sometimes parents were accused of simply wasting money on luxuries such as large televisions or on convenience foods, doing so, some thought, because they knew no better or because they were unnecessarily profligate. However, a minority of respondents offered a different explanation for excessive spending: they understood it to be a form of compensation given stressful lives and as a way of re-engaging in society, an attempt not to feel excluded, different and down-trodden.

And those very same big screen TVs you talk about encourage that, OK? The media, the programs they put on, you got a little nine year old talking like he's 90. And the kids see it, they emulate it, they believe that, that's what's going to happen. They believe that they should have those sneakers that they're bombarded with. So a lot of times, I mean, I don't know if it's just the materialism of the times that do it but you have a lot of people get lost as a result of that. 1/6/12

Turning from consumption to production, many respondents believed that profound changes in the labor market were a major factor increasing poverty: the economy was no longer generating the right kind of jobs. Several reasons were aired to explain this development which some respondents, notably African Americans, felt impacted disproportionally on their 
community. They considered that the new jobs being created demanded high level technical skills and that the education system was failing to provide young people with the competencies now required. Government claims that they would create a balanced economy fit for the Twenty-First Century were not seen to be matched by reality and some felt that employers were exploitative in conditions of surplus labor, not responding to applications and even fabricating posts to recruit people into training and/or temporary work.

Leadership came out and said we need to build a bridge to the 21st Century, okay? Which obviously means the dynamic has to change, okay? You do more work electronically, okay? There's less manual type labor, okay? Less unskilled labor, alright? But our educational system isn't geared to put our kids in that electronic age. (2) $1 / 24 / 6$

The number of manual and unskilled job opportunities was falling quickly, partly, some thought, because many jobs were going overseas, leaving New Yorkers with only poorly paying employment opportunities. Furthermore, locals were perceived to be losing out to the large number of immigrants who were often not only believed to be very motivated and prepared to work for next to nothing but were also receiving special assistance from the authorities.

With upward mobility, we had a chance for a pension. Those things are not there now. Jobs are overseas and if you do get a job, like you might have to have two parttime jobs with no health benefits, no pension and they are working you like a dog. (1) $4 / 12 / 3$

Sure, you have a lot of foreigners coming over with money and they are giving them grants and money to start businesses. We don't have that opportunity any more. It's not the same. (2)4/8/1

The net result of these labor changes, respondents understood, was to deny people good employment and incomes, potentially leaving some so disillusioned and despairing that they developed the mind-set previously characterized as a poverty of spirit.

You have to be pretty tough to get through it and if you don't have the tenacity and you don't have the upbringing to do that, it's hard and it's very easy to walk away. And it's very easy to fail...to fall into a category where you say 'I can't do anything!'. $(2) / 23 / 5$ 
For respondents, the combination of influences, social, policy and economic, served not only to provide a satisfactory explanation of 'mental poverty' but also supported the widespread belief that poverty was intergenerational. For example, it was sometimes argued that lack of opportunities in the labor market, high housing costs, means-tested public housing and poor educational provision led indirectly to fatalistic and passive attitudes because people's aspirations were thwarted by severely constrained choice. More often, it was contended that welfare provision, poor parenting, and bad neighborhoods, often compounded by the continuing legacy of a racism, served directly to produce a mental poverty depicted by lack of ambition, laziness and wrong choices. Given the lack of positive role models within the neighborhood and the surfeit of negative ones in the housing projects, among peers and within dysfunctional families, it was considered almost inevitable that individuals would repeat the mistakes of their parents and peers, thus perpetuating the persistence of poverty from one generation to the next.

They can't snap out of it. They don't know any better. They're doing and repeating what they see around them. They're doing the best they can. They are aware of the fact that there's another way to live. They even refer to it as: 'So-and-so broke out of our group and is living the big life', but they don't know what to do to get there. They want to get there. They know somebody's done it, but they don't have the skills, the information. It's not that they don't have the brains to do it. It's that they haven't been trained to do it. (1) $2 / 2 / 3$

\section{Discussion: perpetuating myth}

The discourse of New Yorkers with moderate means gathered from group discussions reveals a coherent model of poverty. Poverty is considered to be attitudinal as much as it is material. A lack of moral fiber, ambition and will-power results in behavioral traits, notably laziness, complacency, the keeping of bad company and a lack of forethought, that combine to reproduce poverty across the generations. Poverty has become a permanent phenomenon that is structured and exacerbated by poor policy making, technological development and social change with the breakdown of traditional family values, the loss of community but also the 
persistence of racism albeit different from in the past. While it would be wrong to assert a uniformity of view, or to suggest that individuals participating in the research would have been able fully to articulate the complexities of this model before discussion, most would very probably adhere to the broad structure of the argument. It is perhaps noteworthy that most respondents were women and people of color, groups that tend to have more progressive social attitudes (Holman et al., 2017; Jost et al., 2015).

Majority scientific opinion would prioritize structural economic forces, notably the allocation and redistribution of income and wealth, as the principal causes of poverty not individual failings. It is important therefore to ask what explains the discrepancy between scientific studies and the analysis offered by respondents. New York is a city of great inequality and notable residential segregation such that, as respondents acknowledged, poverty was usually only viewed from a distance. While some respondents had escaped from poverty, the understanding of most must have been mediated through media, public and political discourse. Of real importance, in this regard, seems to be attachment to the ideal of the American Dream. For respondents, this was not just an attachment to the work ethic but the sense that the USA was created as a land of opportunity and that, even though the opportunities were not equal and might be getting less, it was incumbent of all citizens to have ambitious aspirations and to pursue them with energy and determination. Poverty, therefore, was evidence of not having pursued the Dream, of lacking aspirations, even of failing to be a good American.

The problem is people do look at America as the land of opportunity. But they seem to believe that means: 'I should be successful and rich'. No, what you put in is what you get out. You still have to do some work, you still have to start somewhere and people just want to start at the middle or the top. (2)1/26/3-3

As a nation of immigrants, most respondents felt that they too had once been at the bottom of the heap even if, in reality, it had been their distant forebears. Therefore, respondents believed that they knew what poverty was like and that one needed grit to get out of it. First 
generation immigrants remembered the pressures of arrival and their obligations to people 'back home'. Discussion of a vignette of an immigrant struggling with such issues stimulated empathy rather than sympathy; respondents recognized the dilemmas but blamed the individual for not doing better.

He has not really established himself. He has lost goal and he has no focus. There's not any reason for anyone to be in any country for 23 years and be still finding it difficult to get money to fly home. That man has no future because sending money back home is one of the major problems of Africa but that doesn't stop us from doing what we are supposed to do, to establish ourselves or where we find ourselves. So he has missed it because he did not have the initial zeal to establish himself. (9)3/18/4

Because respondents believed in the American dream, they largely accepted all but the extremes of the resultant pattern of inequality and were generally comfortable about their place in the economic hierarchy. They felt that they had worked hard, sustained the hardships and made the right choices and consequently had succeeded where others had failed. Adherence to the Dream simultaneously justified their own comparative affluence while explaining the existence of poverty as a personal rather than a social problem. They could sleep at night untroubled by the existence of poverty.

The same underlying logic muted concerns about many of the structural causes of poverty that were identified: poor policy; fragmented families; disaffected neighborhoods; and racism. While acknowledging that the structural constraints on individual progress might be getting worse, respondents considered that they themselves had had to negotiate the same obstacles or their parents had before them. This might well apply to racism as it did to other factors. For members of the African American community, racism was generally seen as the singular most important cause of poverty which was viewed as a structural product of a racist society in which economic and other developments were systematically eroding community cohesion and blocking routes of advancement for African Americans. The group composed solely of African Americans frequently equated poverty with racism and made no reference to poverty among other racial groups. Equally, they explained their own advancement in 
terms of energy, determination and parental support, qualities that by implication others lacked and who, as a consequence, remained poor. Other African Americans were more forthright in their condemnation of people who were in poverty:

If you have done no work, if all you have done is shown in a tank top with your pants around your ass, you do not deserve to be where I am. You don't! (1)1/25/3

The general distaste for welfare described above can be interpreted through a similar selfjustifying lens. The term 'welfare' was seldom specifically defined but was generally taken to refer to any financial benefit thought to be accessible by people living in poverty. It was almost universally considered to be either an unfortunate necessity or an unwelcome anathema that undermined the work ethic, rewarded laziness and antisocial behavior and created a mutual sense of alienation between the recipient and the tax-payer. To be in receipt of welfare was to be dependent not independent, defeatist rather than pioneering. Worse it was the refuge of freeloaders and the amoral. It was un-American.

Respondents often defined themselves as never having been on welfare or having 'escaped' welfare which unwittingly embroiled them in a discourse of moral superiority. Whereas welfare recipients were thought often to be abusing the system, they had used it judiciously, for the purpose intended even when their behavior was questionable or sanctioned as illicit. The justification was in terms of what they had done subsequently: found jobs; put their families first; and been materially successful. The fact that they were not income poor served to prove that they were similarly not poor in spirit; rather they were true Americans.

The article began with a big question: Why is there so little sustained, popular support for reducing the US poverty rate given that it so high by international standards? In terms of recent political history, this lack of support finds reflection in the limited attention paid to poverty in the 2016 Presidential Election. It concludes with the hypothesis that Americans 
may ascribe to a self-justifying, explanatory model of poverty that uniquely reflects the American Dream and which legitimates the status-quo.

The model or cultural schema is consistent with attribution (Feagen, 1975), dual consciousness (Hunt,1996; Kluegel et al., 1995) and legitimation theories (Sidanius and Pratto, 1999; Jost et al., 2012) and supplies the cognitive links between them. Unlike most studies, poverty was neither assumed nor defined in advance; instead respondents were invited to define poverty in their own terms. Most respondents conflated the definition of poverty with the attribution of causality. They simultaneously equated poverty with limited resources and behavioral deficiencies, both of which were considered to result from structural processes but also, in their turn, to contribute to the perpetuation of poverty.

It must be stressed that the model derives from inductive analysis of discussions with a small number of middle class New Yorkers and thus it is for the reader to determine whether the model warrants further empirical enquiry. While congruent with the simultaneous endorsement of individualistic and structuralist explanations of poverty frequently reported in the US, it deviates from much international research which suggests that people attribute poverty to either individual or structural factors depending on their political orientation on a right-left spectrum (Oorschot et al., 2008; Walker, 2014). 


\section{References}

Alesina, A. \& Glaeser, E. (2004). Fighting Poverty in the U.S. and Europe: A World of Difference, New York: Oxford University Press.

Beeghley, L. (2004). The Structure of Social Stratification in the United States. Boston, MA: Pearson

Brown, H. (2013). The new racial politics of welfare: Ethno-racial diversity, immigration, and welfare discourse variation. Social Service Review, 87, 586-612.

Campbell, C. (2016). The formative years, economic hardship, and beliefs about the government's role in lessening poverty. Social Problems, 63, 244-265.

Chase, E., \& Bantebya-Kyomuhendo, G. (Eds.). (2014). Poverty and shame: Global experiences. Oxford: Oxford University Publications.

Feagin, J. (1972). When It Comes to Poverty, It's Still, 'God Helps Those Who Help Themselves'. Psychology Today 6, 101-29.

Glaser, B. \& Strauss, A., (1967). The Discovery of Grounded Theory: Strategies for Qualitative Research, Chicago, Aldine Publishing Company

Godfrey, E. \& Wolf, S (2016). Developing critical consciousness or justifying the system? A qualitative analysis of attributions for poverty and wealth among low-income racial/ethnic minority and immigrant women. Cultural Diversity \& Ethnic Minority Psychology, 22, 93-103.

Haaretz, (2016) 'U.S. Poverty is a 'Death Sentence' Similar to Conditions in 'Palestine",' Says Sanders', Haaretz. Retrieved May 15, http://www.haaretz.com/world-news/u-selection-2016/1.7 16138

Halpin, J. \& Agne, K. (2014) 50 Years After LBJ's War on Poverty: A Study of American Attitudes About Work, Economic Opportunity, and the Social Safety Net, Washington DC: Half in Ten Education Fund and the Center for American Progress

Hasenfeld, Y. \& Rafferty J. (1989). The determinants of public attitudes toward the welfare state. Social Forces, 67, 1027-48.

Haskins, R. (2016). What are the presidential candidates saying about poverty and opportunity? Washington DC: Brookings Paper.

Homan, P., Valentino, L. \& Weed, E. (2017). Being and Becoming Poor: How Cultural Schemas Shape Beliefs About Poverty. Social Forces 95(3) 1023-1048.

Hunt, M. (1996). The Individual, Society, or Both? A Comparison of Black, Latino, and White Beliefs about the Causes of Poverty. Social Forces 75, 293-322. 
Hunt M \& Bullock H. (2016). Ideologies and Beliefs about Poverty In D. Brady \& L. Burton (Ed.) The Oxford Handbook of the Social Science of Poverty. (93-116). New York: Oxford University Press.

Jones, S. (1985). The analysis of depth interviews. In R. Walker (Ed.), Applied Qualitative Research (56-70). Aldershot: Gower Publication Company.

Jost, J., Chaikalis-Petritsis, V., Abrams, D., Sidanius, J., van der Toorn, J., \& Bratt, C. (2012). Why men (and women) do and don't rebel: Effects of system justification on willingness to protest. Personality and Social Psychology Bulletin, 38,197-208.

Jost, J., Basevich, E., Dickson, E. \& Noorbaloochi, S. (2015). The place of values in a world of politics: personality, motivation, and ideology. Pp. 351-374 in Brosch, T. and Sander, D. (eds.) Handbook of Value: Perspectives from Economics, Neuroscience, Philosophy, Psychology and Sociology, Oxford: Oxford University Press

Kluegel, J. \& Smith, E. (1981). Beliefs about Stratification. Annual Review of Sociology 7 , $29-56$.

Kluegel, J., Mason, D. \& Wegener, B. (1995). Social Justice and Political Change-Public Opinion in Capitalist and Post-communist States. New York: Aldine de Gruyter.

Margalit, Y. (2013). Explaining social policy preferences: Evidence from the Great Recession. American Political Science Review, 107, 80-103.

O'Connor, P. (2014) Attitudes Toward Poverty Show Dramatic Change — WSJ/NBC Poll, Washington Wire, http://blogs.wsj.com/washwire/2014/06/20/attitudes-towardpoverty-show-dramatic-change-wsjnbc-poll/

Organization of Economic Cooperation and Development. (2016).

https://data.oecd.org/inequality/poverty-rate.htm.

Oorschot, W. van, Opielka, M. \& Pfau-Effinger, B. (Eds.) (2008) Culture and Welfare State Values of Social Policy from a Comparative Perspective. London: Edward Elgar.

Owens, L. \& Pedulla, D. (2014). Material welfare, ideology, and changing political preferences: The case of support for redistributive policies. Social Forces, 92, 1087 113.

Pew Research Center. (2012). Partisan Polarization Surges in Bush, Obama Years, http://www.people-press.org/2012/06/04/partisan-polarization-surges-in-bush-obamayears.

Pew Research Center. (2015). Public's Policy Priorities Reflect Changing Conditions At Home and Abroad, Pew Research Center, January. www.peoplepress.org/files/2015/01/01-15-15-Policy-Priorities-Release.pdf.

Rose, M. \& Baumgartner, F. (2013). Framing the poor: Media coverage and U.S. poverty policy, 1960-2008. Policy Studies Journal, 41, 22-53. 
Santiago, A. (2015), Fifty years later: From a war on poverty to a war on the poor. Social Problems, 62, 2-14.

Sidanius, J. \& Pratto, F. (1999) Social Dominance: An Intergroup Theory of Social Hierarchy and Oppression. Cambridge, MA: Cambridge University Press.

Stephenson, E. (2016). Drowned out in noisy campaign, Republicans revive poverty message. Retrieved from http://www.reuters.com/article/us-usa-election-povertyidUSKBNOUM29T20160108

Strauss, C. \& Quinn, N. (1997). A Cognitive Theory of Cultural Meaning. Cambridge: Cambridge University Press.

Walker, R. (2014). The Shame of Poverty. Oxford: University of Oxford.

Wessler, S. (2014). Fewer Americans Blame Poverty on the Poor.NBCNews.com, June 20. Retrieved from www.nbcnews.com/feature/in-plain-sight/poll-fewer-americansblame-poverty-poor-n136051.

Wise, T. (2014). The Culture of Cruelty: How America's Elite Demonize the Poor, Valorize the Rich and Jeopardize the Future, San Francisco: City Lights. Retrieved from http://www.timwise.org/2014/11/poverty-denialism-in-a-culture-of-cruelty-bashingthe-poor-as-right-wing-amusement/

\footnotetext{
'A pragmatic approach was taken to the definition of middle class. Respondents were identified as not poor due to not receiving welfare benefits and middle class by reference to their occupation and neighborhood characteristics, gentrifying areas adjacent to high poverty zip codes. This operationalisation perhaps corresponds most closely with Beeghley's (2004) conceptualisation of middle class

ii The group discussions were conducted after completing interviews with 60 people in poverty in three high poverty zip codes in New York. Each was moderated by two researchers and were mostly triggered by two
} 
exercises. For the first, respondents were asked individually to write on cards single reasons why they thought that people ended up on a low income or living in poverty. The cards were placed face down and selected by group members for discussion. The second exercise involving sharing with the group brief anonymised excepts from the transcripts of the interviews conducted people in poverty. These were selected to capture ways in which people in poverty felt excluded from and by wider society. 